Historic, archived document

Do not assume content reflects current scientific knowledge, policies, or practices. 

499.9

F76224

USDA United States

Department of

Agriculture

Gy Forest Service

Northeastern

Research Station

Research Note NE-378

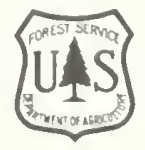

\section{Summer Roost-Tree Selection by a Male Indiana Bat on the Fernow Experimental Forest}

\author{
W. Mark Ford \\ Jennifer M.Menzel \\ Michael A. Menzel \\ John W. Edwards
}

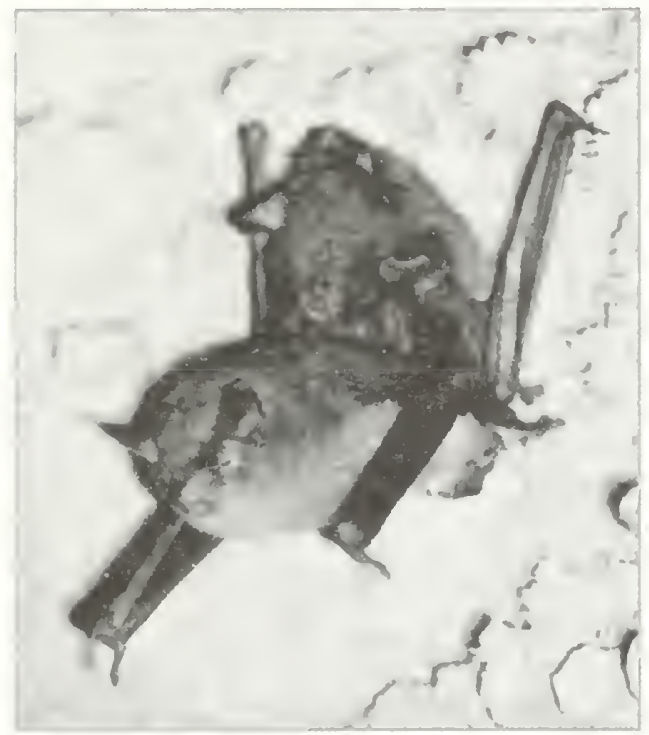

\section{Abstract}

We attached a radio transmitter to an adult male Indiana bat (Myotis sodalis) in June 2001 on the Fernow

Experimental Forest in the Allegheny Mountains of north-central West Virginia. The bat was tracked for 4 successive days before the transmitter failed. The bat roosted in three living trees over the study period. Tivo roosts used for a single night each were in large shagbark hickories (> $45 \mathrm{~cm}$ d.b.h.); the roost used for two successive nights was located in a large sugar maple (69.1 $\mathrm{cm}$ d.b.h.). Roost trees were characterized by large areas of exfoliating bark and all were canopy-dominant within surrounding stands. One shagbark hickory was a residual tree left following a patch clearcut 6 years earlier. Although few inferences can be drawn from one Indiana bat, many characteristics of this individuals's roost selections in the central Appalachians were consistent with tree roosts observed in other regions during the nonhibernation period of this species.
The majority of the Indiana bat's (Myotis sodalis) winter hibernacula and summer maternity range is in the lower Ohio Valley and Ozark Plateau of the Midwest (Menzel et al. 2001b). However, there are 92 Priority II and III hibernacula of this endangered species in the central and southern Appalachians from northeastern Alabama to central Pennsylvania (Humphrey 1978; USDI Fish and Wildl. Serv. 1999; Menzel et al. 2001b). Summer maternity activity of female Indiana bats is believed to be rare in forest habitats in the central Appalachians of Virginia and West Virginia (Brack et al. 2001; Owen et al. 2001). However, most male Indiana bats remain in the

W. MARK FORD and JENNIFER M. MENZEL, research wildlife biologists, USDA Forest Service, Northeastern Research Station, Parsons, West Virginia; MICHAEL A. MENZEL, graduate research assistant, and JOHN W. EDWARDS, assistant professor, West Virginia University, Division of Forestry, Morgantown, West Virginia. 
hibernacula vicinity and use trees and snags as day roosts during late spring, summer, and early fall. Accordingly, protection of tree roosts and forested habitat around Indiana bat hibernacula in the Appalachians is important to safeguard males from direct mortality and/or harmful modification of their roosting and foraging habitat.

Within the central and southern Appalachians, published roost research on male Indiana bats has been limited to a study of immediate post-hibernation emergence in the Ridge and Valley of western Virginia (Hobson and Holland 1995) and two pre-hibernation studies conducted just before and during fall "swarm" on the Cumberland Plateau in eastern Kentucky (Kiser and Elliot 1996; MacGregor et al. 1999). Although critical for natural resource managers in a region where forest management is substantial on private lands (DiGiovanni 1990) while decreasing rapidly on public lands (Ford et al. 2000), there are few data on roost characteristics of male Indiana bats during the non-hibernation spring and summer seasons. The objective of this study was to provide preliminary data on male Indiana bat day roosts in the central Appalachians of West Virginia and relate those findings to current forest management practices.

\section{Study Area and Methods}

We examined summer day roosts of a male Indiana bat on the Fernow Experimental Forest, a 1,900-ha research forest located in Tucker County, West Virginia. Elevations in this portion of the Allegheny Mountains subsection of the Unglaciated Appalachian Mountains and Plateau Physiographic Province generally range from 600 to 1300 $\mathrm{m}$. Topography is characterized by steep side slopes with broad ridge tops and narrow valleys (Fenneman 1938). The climate is cool and moist with annual precipitation exceeding $155 \mathrm{~cm}$ (Madarish et al. 2002). On upland sites, mature (> 70 years), second-growth Allegheny/ northern hardwood forests are dominated by American beech (Fagus grandifolia), sugar maple (Acer saccharum), red maple (A. rubrum), black cherry (Prunus serotina), northern red oak (Quercus rubra), yellow birch. (Betula alleghaniensis), black birch (B. lenta), Fraser magnolia (Magnolia fraseri), and basswood (Tilia americana). Riparian areas on the Fernow are dominated by eastern hemlock (Tsuga canadensis) and rosebay rhododendron (Rhododendron maximum). Because the Fernow is designated as a forestry research area, it contains younger forest stands ( $<10$ years) that originated from clear-and deferment cutting and older stands altered by diameterlimit and selection cutting.

Portions of the Fernow and surrounding landscape in eastern West Virginia are underlain by the Greenbrier Limestone strata (Madarish et al. 2002) with karst formations and numerous caves. Locally, several of these caves serve as minor hibernacula for Indiana bats. Big Springs Cave, located near the center of the Fernow, annually winters approximately 200 male and female Indiana bats. During the summer maternity season, female Indiana bats probably are absent throughout most of the Allegheny Mountains of West Virginia, including the Fernow (Owen et al. 2001). Male Indiana bats that hibernate in Big Springs Cave remain in and around the Fernow ( $\leq 25 \mathrm{~km}$ radius) during the spring, summer and fall where they day roost in trees (L. E. Thomasma, USDA Forest Service, commun.). As a result, timber harvests for research purposes on the Fernow are limited to October 1 through April 30 to avoid "take" of an endangered species through habitat modification or direct mortality that could occur by felling an occupied roost tree. ${ }^{1}$

On 16 June, 2000, at approximately $2200 \mathrm{hr}$, we captured a male Indiana bat with a single mist net placed over Elklick Run near the center of the Fernow Experimental Forest. We confirmed species identification by the presence of a keeled calcar and short toe hairs that did not extend beyond the knuckle or claw (Whitaker and Hamilton 1998). The bat had the following measurements: forearm $38 \mathrm{~mm}$, ear $8.5 \mathrm{~mm}$, tragus 6 $\mathrm{mm}$, and mass $7.0 \mathrm{~g}$. We assigned the bat to the adult age class by examining the degree of epiphyseal-diaphyseal fusion (Anthony 1988; Racey 1988). We attached a 0.51g model LB-2 radio transmitter (Holohil Systems Ltd., Woodlawn, $\mathrm{ON})^{2}$ to the hair between the bat's scapula using Skin Bond ${ }^{\circledR}$ surgical adhesive (Pfizer Hospital Products Group, Largo, FL). Transmitter mass was approximately 7 percent of the bat's body weight, slightly in excess of the recommended 5 percent of body mass (Aldridge and Brigham 1988). We used LA12-Q AVM receivers (AVM Instruments, Colfax, CA) and folding, three-element Yagi antennas to locate the Indiana bat's day roosts. The bat was tracked for 4 successive days before the transmitter was shed.

At each day roost or within a 10 -m-radius circular plot with the roost as plot center, we recorded roost-tree species, d.b.h. (cm), height $(\mathrm{m})$, snag class, bark-cover

${ }^{1}$ Adams, M. B., Knibbs, J., Rodrigue, J. L., Edwards, P. J., Wood, F., Ford, W. M., Kochenderfer, J. A., Schuler, T. M., Crews, J. 2000. Fernow Experimental Forest: environmental impact statement, Final Rep. On file at the Northeastern Research Station, Newtown Square, Pennsylvania.

${ }^{2}$ The use of trade, firm, or corporate names in this report is for the information of the reader. Such use does not constitute an official endorsement or approval by the USDA Forest Service of any product or service to the exclusion of others that may be suitable. 
Table 1.-Summer day-roost characteristics for an adult male Indiana bat on the Fernow Experimental Forest, Tucker County

\begin{tabular}{|c|c|c|c|c|c|}
\hline Variable & Roost 1 & Roost 2 & Roost 3 & Mean & $\mathrm{SE}$ \\
\hline Tree species & C. ovata & C. ovata & A. saccharum & & \\
\hline d.b.h. $(\mathrm{cm})$ & 45.5 & 68.0 & 69.1 & 60.9 & 7.7 \\
\hline Height (m) & 32.5 & 30.0 & 25.8 & 29.4 & 2.0 \\
\hline Snag class & 1 & I & I & & \\
\hline Bark cover & IV & IV & IV & & \\
\hline Linearized aspect & 2.7 & 3.5 & 3.9 & 3.4 & 0.4 \\
\hline Slope $(\%)$ & 38 & 57 & 83 & 59.3 & 13.1 \\
\hline Elevation (m) & 800 & 800 & 702 & 767.2 & 32.9 \\
\hline Stand type & N. Hardwood & N. Hardwood & N. Hardwood & & \\
\hline Canopy cover & III & I & V & & \\
\hline Midstory layer & IV & V & III & & \\
\hline Seedling layer & I & II & II & & \\
\hline Litter depth & II & II & III & & \\
\hline \multicolumn{6}{|l|}{ Distance (m) to: } \\
\hline Nearest water & 243 & 85 & 53 & 127.2 & 58.7 \\
\hline Elklick Run & 740 & 803 & 618 & 720.3 & 54.4 \\
\hline Nearest road & 43 & 49 & 13 & 35.0 & 11.2 \\
\hline Capture site & 868 & 905 & 643 & 805.3 & 82.0 \\
\hline Big Springs Cave & 1275 & 1588 & 1980 & 1614.3 & 204.2 \\
\hline
\end{tabular}

class, site aspect, elevation $(\mathrm{m})$, surrounding forest-stand community, canopy cover, midstory and woody-seedling density, litter depth, and distance $(\mathrm{m})$ to nearest water, to Elklick Run, to nearest road, to the capture site, and to Big Springs Cave. We used a laser rangefinder to determine roost height and the distance to the nearest road. Site aspect was linearized using ( 1 -cosine [aspect degrees] + 1-sine[aspect degrees]) with values increasing from mesic, northern aspects to xeric, southwestern aspects (Odom et al. 2001). Following Maser et al. (1979), we assessed snags from 1-7, with 1 a live tree and 7 a decomposing broken bole. We rated bark-cover class as I (none), II ( $<10$ percent), III (10-25 percent) and IV (>25 percent). We grouped visual estimates of canopy cover, midstory density, and woody-seedling and herbaceous groundlayer density in five classes: I ( $0-5$ percent), II (5-25 percent), III (26-50 percent), IV (51-75 percent), V (76-95 percent), and VI (96-100 percent). We rated litter depth as I (none), II $(\leq 2.54 \mathrm{~cm})$, III $(2.55-6$ $\mathrm{cm})$, and IV $(>6 \mathrm{~cm})$. We calculated elevation and distances from roosts to nearest water, Elklick Run, capture location, Big Springs Cave, and other roost trees using ArcView 3.2 GIS (ERSI, Redlands, CA) .

\section{Results and Discussion}

Over a 4-day period, we tracked the male Indiana bat to three different roosts (Fig.1), all of which were Stage 1 live trees with abundant exfoliating bark (> 25 percent bole surface area) and no visible cavity or wound (Table 1). Roosts 1 and 2 were large shagbark hickories (Carya ovata) used by the bat for 1 day each (Table 1). Roost 3 was a large sugar maple that was used by the bat for 2 successive days (Table 1). All roosts were located in mesic Allegheny/northern hardwoods communities on sites with northwest to northeast aspects (Table 1). Roosts 1 and 3 were in mature forest stands characterized by numerous large trees. Roost 2 was a residual tree in a patch clearcut. The stand had been harvested in 1995 and was dominated by abundant woody regeneration 3 to $4 \mathrm{~m}$ high. Roosts 1 and 3 were canopy-dominant trees, though neither extended above the canopy. Each day roost was < $50 \mathrm{~m}$ from a road, $<300 \mathrm{~m}$ to the nearest water, $<1,000$ $\mathrm{m}$ to Elklick Run and the capture site, and $<2,000 \mathrm{~m}$ to Big Springs Cave (Table 1). Distances from Roost 1 to Roost 2, Roost 2 to Roost 3, and Roost 1 to Roost 3 were 340,477 , and $705 \mathrm{~m}$, respectively. 


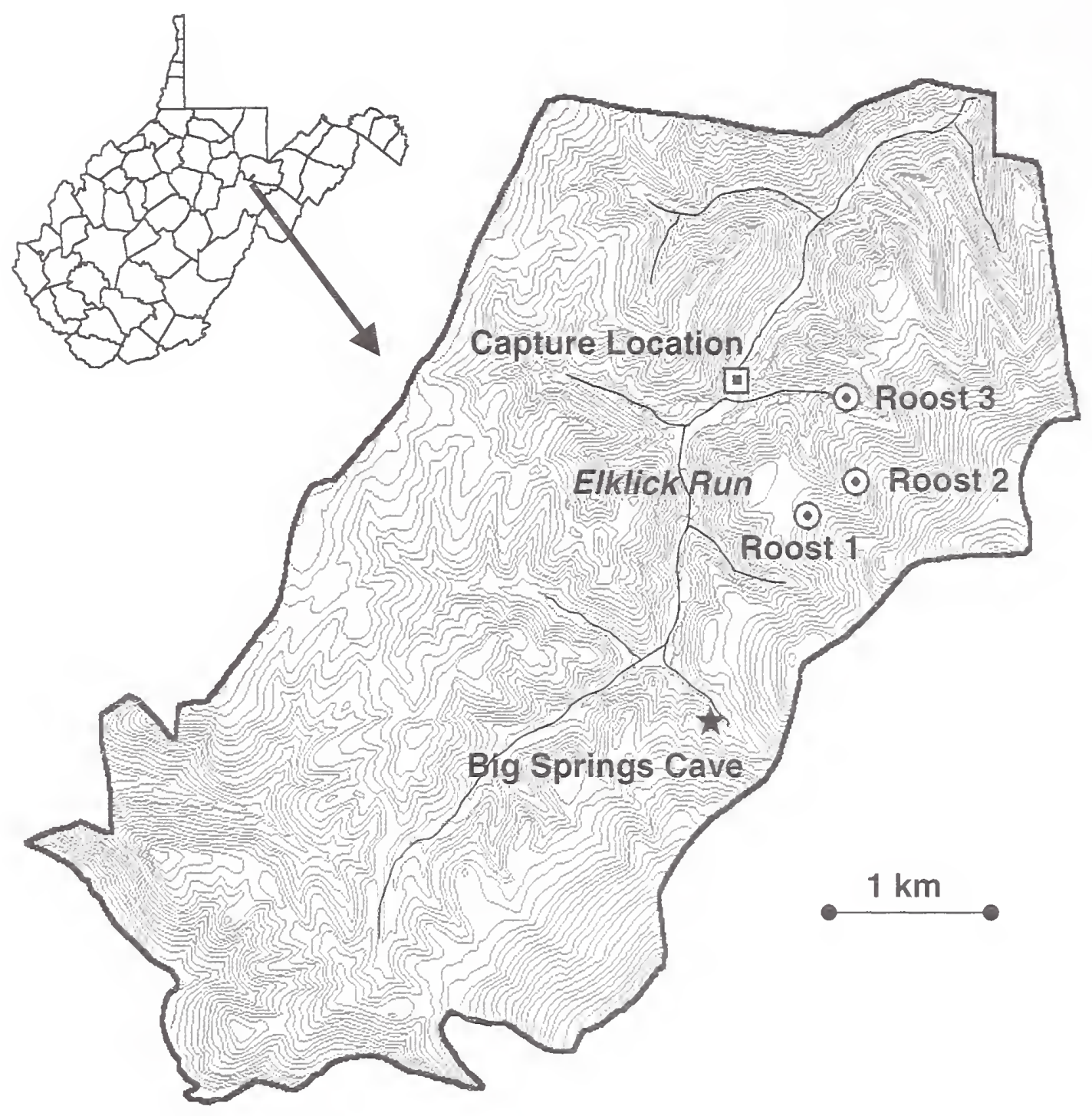

Figure 1.-Capture site and day roosts of a male Indiana bat in relation to Big Springs Cave and Elklick Run on the Fernow Experimental Forest in West Virginia.

Tree-roosting bats generally select trees that are larger in diameter and taller than the surrounding stand (Sasse and Perkins 1996; Vonhof and Barclay 1996; Callahan et al. 1997; Foster and Kurta 1999). Although both male and female Indiana bats show large rangewide variation in the size ( 8 to $86.6 \mathrm{~cm} \mathrm{d.b.h)} \mathrm{and} \mathrm{types} \mathrm{of} \mathrm{trees} \mathrm{or} \mathrm{snags}$ chosen for roosts (Menzel et al. 2001b), Kurta et al. (1996) found that roost trees tended to be larger on average than other trees in the surrounding stand. The three roosts on the Fernow were similar to or larger than the majority of live trees or dead snags used by females at maternity roosts in the Midwest (Gardner et al. 1991; Kurta et al. 1996; Callahan et al. 1997) or as day roosts for males in the early spring or late fall in the Appalachians (Hobson and Holland 1995; Kiser and Elliot 1996; MacGregor et al. 1999). Female bats often choose a large tree or snag that extends to the canopy or above to take advantage of increased solar exposure that keeps the roost warm and aids the growth and development of juvenile bats (Menzel et al 2001a). Presumably, male Indiana bats roosting in and around Big Springs Cave are not so constrained because all three roosts were situated on more northern (cooler) aspects. Callahan er al. (1997) speculated that male Indiana bats seek cooler roosts to conserve energy. Other measured variables such as canopy cover were similar to or within ranges reported for tree roosts from throughout the Indiana bat's distribution (Menzel et al. 2001b).

Rangewide, Indiana bats show an affinity for roost trees with exfoliating bark (Rommé et al. 1995; Callahan et al. 1997). Menzel et al. (2001b) identified snags of 23 tree 
species used by Indiana bat as day roosts. Shagbark hickory, noted for extensive amounts of exfoliating bark, was the lone live species often used for roosts (Humphrey et al. 1977; Gardner et al. 1991; Callahan et al. 1997). The large sugar maple identified as a roost also had a substantial amount of exfoliating bark. Because shagbark hickory is such a minor forest component within the Fernow's Allegheny/northern hardwood type, male Indiana bats might be showing strong preference for this tree species. Unfortunately, in the absence of even-age silviculture and with continued fire suppression, heavy seeded, shade-intolerant species such as shagbark hickory continue to decrease in importance on the Fernow and surrounding landscape (Schuler and Gillespie 2000). However, the large increase in dominance of sugar maple across the Fernow partially could offset losses of shagbark hickory.

Regardless, it seems appropriate to retain large live trees or dead snags within predetermined radii around Indiana bat hibernacula in the central and southern Appalachians where males may roost in spring through early fall, and to prohibit forest harvesting within that area during the non-hibernation season (Kiser and Elliot 1996). Within these hibernacula zones and at the appropriate season, two-age or deferment harvests (Miller et al. 1995; Johnson et al. 1998) that retain large shagbark hickory, sugar maple, or other trees with exfoliating bark would provide timber products and adequate regeneration while protecring the Indiana bat and its habitat.

Spatially, the locations of the three day roosts relative to where the male Indiana bat was captured on its presumed foraging area along Elklick Run are well within the ranges of $>200 \mathrm{~m}$ to $2 \mathrm{~km}$ from day roosts to foraging areas reported in the literature (Humphrey et al. 1977; Kurta et al. 1993; Menzel et al. 2001b). On an Appalachian landscape somewhat comparable to the Fernow, Hobson and Holland (1995) observed a 1-km distance between male Indiana bat day roosts and riparian-zone foraging areas in western Virginia during the post-hibernation period in spring. Acoustical survey sampling has indicated that Indiana bats on the Fernow forage extensively along Elklick Run during the summer. ${ }^{3.4}$ Distances between observed roost trees also were within ranges reported for day roosts in the early fall on the Cumberland Plateau (MacGregor et al. 1999). Our observation that the male

'Owen, S. F., Menzel, M. A.; Ford, W. M.; Edwards, J. W.; Menzel, J. M.; Chapman, B. R.; Wood, P. B.; Miller, K. V. Bat activity in managed and unmanaged forest and riparian zones in the Allegheny Mountains. In preparation.

${ }^{4}$ W. M. Ford, unpublished data on file at Northeastern Research Station, Parsons, West Virginia.
Incliana bat we tracked used three day roosts over 4 days was consistent with frequent roost switching ( 1 to 2 days) observed for male Indiana bats in the pre-swarm period in the fall on the Cumberland Plateau (Kiser and Elliot 1996; MacGregor et al. 1999). Additional research and monitoring is needed to determine whether the midsummer roost characteristics we observed are representative of male Indiana bats on the Fernow and/or similar to pre-and post-hibernation data collected from other portions of the central and southern Appalachians.

\section{Acknowledgments}

Field assistance was provided by Jane Rodrigue and Kate Leonard. Funding for this work was provided by the Northeastern Research Station Scientist and the West Virginia Universiry, Swiger Graduate Fellowship. Cover photo courtesy of 'Timothy Carter.

\section{Literature Cited}

Aldridge, H. D.; Brigham, R. M. 1988. Load carrying and maneuverability in an insectivorous bat: a test of the 5\% "rule" of radio-telemetry. Journal of Mammalogy. 69: 379-382.

Anthony, E. L. 1988. Age determination. In: Kunz, T. H., ed. Ecological and behavioral methods for the study of bats. Washington, DC: Smithsonian Institution Press: 47-57.

Brack, V.; Stihler, C. W.; Reynolds, R. J.; Butchkoski, C. 2001. Distribution, abundance, and reproduction by the Indiana bat (Myotis sodalis) in the Appalachian Mountains of the eastern U.S.: affect of elevation. In: Kurta, A. ed. The Indiana bat, biology and management of an endangered species; 2001 March 29-April 1; Lexington, KY. University of Kentucky: 9. Abstract.

Callahan, E. V.; Drobney, R. D.; Clawson, R. L. 1997. Selection of summer roosting sites by Indiana bats (Myotis sodalis) in Missouri. Journal of Mammalogy. 78: 818-825.

DiGiovanni, D. M. 1990. Forest statistics for West Virginia - 1975 and 1989. Resour. Bull. NE-114. Radnor, PA: U. S. Department of Agriculture, Forest Service, Northeastern Forest Experiment Station. 172 p.

Fenneman, N. M. 1938. Physiography of the eastern United States. New York: McGraw-Hill. 714 p.

Foster, R. W.; Kurta, A. 1999. Roosting ecology of the northern bat (Myotis septentrionalis) and 
comparisons with the endangered Indiana bat

(Myotis sodalis). Journal of Mammalogy. 80: 659-672.

Gardner, J. E.; Garner, J. D.; Hofmann, J. E. 1991. Summer roost selection and roosting behavior of Myotis sodalis (Indiana bat) in Illinois. Final Rep. Champaign, IL: Illinois Natural History Survey and Illinois Department of Conservation. 56 p.

Hobson, C. S.; Holland, J. N. 1995. Post-hibernation movement and foraging habitat of a male Indiana bat, Myotis sodalis (Chiroptera: Vespertilionidae), in western Virginia. Brimleyana. 23: 95-101.

Humphrey, S. R. 1978. Status, winter habitat, and management of the endangered Indiana bat, Myotis sodalis. Florida Science. 41: 65-76.

Humphrey, S. R.; Richter, A. R.; Cope, J. B. 1977. Summer habitat and ecology of the endangered Indiana bat, Myotis sodalis. Journal of Mammalogy. 58: 334-346.

Johnson, J. E.; Miller, G. W.; Baumbras, J. E.; West, C. D. 1998. Assessment of residual stand quality and regneration following shelterwood cutting in central Appalachian hardwoods. Northern Journal of Applied Forestry. 15: 203-210.

Kiser, J. D.; Elliot, C. L. 1996. Foraging habitat, food habits, and roost tree characteristics of the Indiana bat (Myotis sodalis) during autumn in Jackson County, Kentucky. Final Rep. E-2. Frankfort, KY: Kentucky Department of Fish and Wildlife Resources. 65 p.

Kurta, A.; Kath, J.; Smith, F. R.; Orick, M. W.; Ross, R. 1993. A maternity roost of the endangered Indiana bat (Myotis sodalis) in an unshaded, hollow, sycamore tree (Platanus occidentalis). American Midland Naturalist. 130: 405-407.

Kurta, A.; Williams, K. J.; Mies, R. 1996. Ecological, behavioral, and thermal observations of a peripheral population of Indiana bats (Myotis sodalis). In: Barclay, R. M. R.; Brigham, R. M., eds. Bats and forests symposium; 1995 October 19-21; Victoria, BC. Victoria, BC: British Columbia Ministry of Forests: 102-117.

MacGregor, J; Kiser, J. D.; Gumbert, M. W.; Reed, T. O.; 1999. Autumn roosting habitat of male Indiana bats (Myotis sodalis) in a managed forest setting in Kentucky. In: Stringer, J. W.; Loftis, D. L. eds.
Proceedings $12^{\text {th }}$ central hardwood forest conference; 1999 February 28-March 1-2; Lexington, KY. Gen. Tech. Rep. SRS-24. Asheville, NC: U.S. Department of Agriculture, Forest Service, Southern Research Station: 169-170.

Madarish, D. M.; Rodrigue, J. L.; Adams, M. B. 2002. Vascular flora and macroscopic fauna on the Fernow Experimental Forest. Gen. Tech. Rep. NE291. Newtown Square, PA: U.S. Department of Agriculture, Forest Service, Northeastern Research Station. 37 p.

Maser, C.; Anderson, R. G.; Cromak, K.; Williams, J. T.; Martin, R. E. 1979. Dead and downed woody material. In: Thomas, J. W., ed. Wildlife habitats in managed forests-the Blue Mountains of Oregon and Washington. Agric. Handb. 533. Washington, DC: U.S. Department of Agriculture: 78-95.

Menzel, M. A.; Carter, T. C.; Ford, W. M.; Chapman, B. R. 2001a. Tree-roost characteristics of subadult and female adult evening bats (Nycticeius humeralis) in the upper Coastal Plain of South Carolina. American Midland Naturalist. 145: 112-119.

Menzel, M. A.; Menzel, J. M.; Carter, T. C.; Ford, W. M.; Edwards, J. W. 2001b. Review of the forest habitat relationships of the Indiana bat (Myotis sodalis). Gen. Tech. Rep. NE-284. Newtown Square, PA: U.S. Department of Agriculture, Forest Service, Northeastern Research Station. 21 p.

Miller, G. W.; Wood, P. B.; Nichols. Two-age silviculture —an innovative tool for enhancing species diversity and vertical structure in Appalachian hardwoods. In: Eskew, L. G., comp. Forest health through silviculture. Proceedings of the 1995 national silviculture workshop. 1995 May 8-11; Mescalero, NM. Gen. Tech. Rep. RM-267. Fort Collins, CO: U.S. Department of Agriculture, Forest Service, Rocky Mountain Forest and Range Experiment Station: 175182.

Odom, R.H.; Ford, W. M.; Edwards, J. W.; Stihler, C.; Menzel, J. M. 2001. Modeling Virginia northern flying squirrel habitat in the central Appalachians. Biological Conservation. 99: 245-252.

Owen, S. F.; Menzel, M. A.; Ford, W. M.; Chapman, B. R.; Miller, K. V.; Edwards, J. W.; Wood, P. B. 2001. First summer record of a female Indiana bat, Myotis sodalis, in West Virginia. Journal of the Elisha Mitchell Scientific Society. 117: 132-134. 
Racey, P. A. 1988. Reproductive assessment in bats. In: Kunz, T. H., ed. Ecological and behavioral methods for the study of bats. Washington, DC: Smithsonian Institution Press: 31-45.

Rommé, R. C.; Tyrell, K.; Brack, V. 1995. Literature summary and habitat suitability index model: components of summer habitat for the Indiana bat, Myotis sodalis. Fed. Aid Proj. E-1-7, Stud. No. 8. Cincinnati, OH: 3D/Environmental. 38 p.

Sasse, D. B.; Pekins, P. J. 1996. Summer roosting ecology of northern long-eared bats (Myotis septentrionalis) in the White Mountain National Forest. In: Barclay, R. M. R.; Brigham, R. M., eds. Bats and forests symposium; 1995 October 19-21; Victoria, BC. Victoria, BC: British Columbia Ministry of Forests: 91-101.
Schuler, T. M; Gillespie, A. R. 2000. Temporal patterns of woody species diversity in a central Appalachian forest from 1856 to 1997. Journal of the Torrey Botanical Society. 127: 149-161.

U.S. Department of Interior, Fish and Wildlife Service. 1999. Indiana bat (Myotis sodalis) revised recovery plan. Fort Snelling, MN: U.S. Department of Interior, Fish and Wildlife Service, Region 3. 53 p.

Vonhof, M. J.; Barclay, R. M. R. 1996. Roost-site selection and roosting ecology of forest-dwelling bats in southern British Columbia. Canadian Journal of Zoology. 74: 1797-1805.

Whitaker, J. O.; Hamilton, W. J. 1998. Mammals of the eastern United States. Ithaca, NY: Cornell University Press, 583 p. 


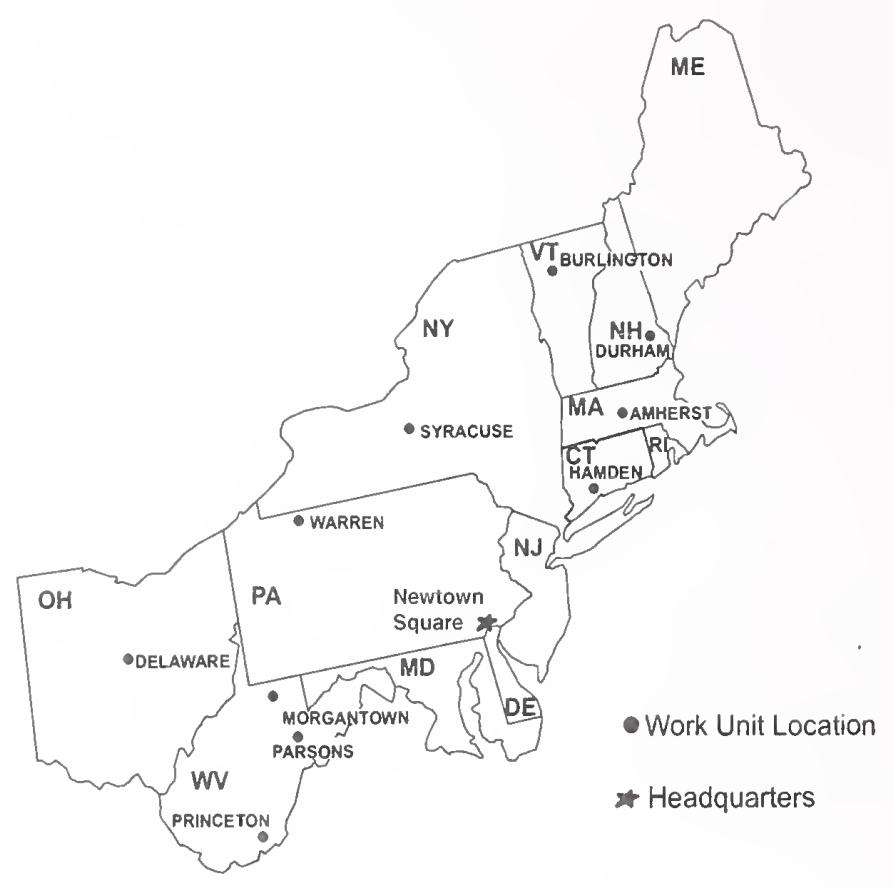

The U. S. Department of Agriculture (USDA) prohibits discrimination in all its programs and activities on the basis of race, color, national origin, sex, religion, age, disability, political beliefs, sexual orientation, or marital or family status. (Not all prohibited bases apply to all programs.) Persons with disabilities who require alternative means for communication of program information (Braille, large print, audiotape, etc.) should contact USDA's TARGET Center at (202)720-2600 (voice and TDD).

To file a complaint of discrimination, write USDA, Director, Office of Civil Rights, Room 326-W, Whitten Building, 1400 Independence Avenue, SW, Washington, DC 20250-9410, or call (202)720-5964 (voice or TDD). USDA is an equal opportunity provider and employer.

MANUSCRIPT RECEIVED FOR PUBLICATION 13 MAY 2002

Published by:

USDA FOREST SERVICE

11 CAMPUS BLVD SUITE 200

NEWTOWN SQUARE PA 19073

July 2002
For additional copies:

USDA Forest Service

Publications Distribution

359 Main Road

Delaware, $\mathrm{OH} 43015$

Fax: (740)368-0152

Visit our homepage at: http://www.fs.fed.us/ne 